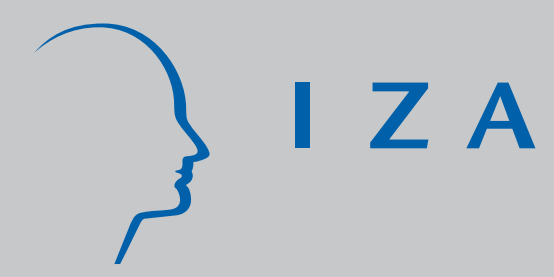

IZADP No. 2038

New Workplace Practices and the Gender Wage Gap:

Can the New Economy be the Great Equalizer?

Nabanita Datta Gupta

Tor Eriksson

March 2006 


\title{
New Workplace Practices and the Gender Wage Gap: Can the New Economy be the Great Equalizer?
}

\author{
Nabanita Datta Gupta \\ Danish National Institute of Social Research, \\ Aarhus School of Business and IZA Bonn \\ Tor Eriksson \\ Aarhus School of Business
}

Discussion Paper No. 2038

March 2006

\author{
IZA \\ P.O. Box 7240 \\ 53072 Bonn \\ Germany \\ Phone: +49-228-3894-0 \\ Fax: +49-228-3894-180 \\ Email: iza@iza.org
}

\begin{abstract}
Any opinions expressed here are those of the author(s) and not those of the institute. Research disseminated by IZA may include views on policy, but the institute itself takes no institutional policy positions.

The Institute for the Study of Labor (IZA) in Bonn is a local and virtual international research center and a place of communication between science, politics and business. IZA is an independent nonprofit company supported by Deutsche Post World Net. The center is associated with the University of Bonn and offers a stimulating research environment through its research networks, research support, and visitors and doctoral programs. IZA engages in (i) original and internationally competitive research in all fields of labor economics, (ii) development of policy concepts, and (iii) dissemination of research results and concepts to the interested public.
\end{abstract}

IZA Discussion Papers often represent preliminary work and are circulated to encourage discussion. Citation of such a paper should account for its provisional character. A revised version may be available directly from the author. 


\section{ABSTRACT}

\section{New Workplace Practices and the Gender Wage Gap: Can the New Economy be the Great Equalizer?*}

We estimate the effect of introducing new workplace practices on the gender gap in wages in the manufacturing sector. We use a unique 1999 survey on work and compensation practices of Danish private sector firms merged to a large matched employer-employee database. Selfmanaged teams, project organisation and job rotation schemes are the most widely implemented work practices. Our estimates from a difference-in-differences model of wages and work practices show that the wage gains from adopting new workplace practices accrue mainly to males so that the gender gap in pay increases at the level of the firm, in particular among hourly-paid workers. Considering practices individually, however, a few exceptions are seen: the gender wage gap among salaried workers is significantly reduced in firms which offer project organisation, while the gap in pay among workers paid by the hour is significantly reduced with the use of quality control circles. All in all, however, the new economy is not the great equalizer.

JEL Classification: J16, J31, M54

Keywords: new workplace practices, employer-employee data, wage differentials, gender

Corresponding author:

Nabanita Datta Gupta

Danish National Institute of Social Research

Herluf Trolles Gade 11

DK-1052 Copenhagen K

Denmark

Email: ndg@sfi.dk

\footnotetext{
*We thank Kathryn Shaw, Lisa Lynch, Edward Lazear, Nancy Beauliu, Jeremy Fox, Illoong Kwon, Kjell Salvanes, Erling Barth, Harald Dale-Olsen, Mette Lausten and participants of the CCP 2005 Christmas Seminar and a seminar at NTU (Taipei) for helpful comments as well as session participants of the AEA conference, Mons, Belgium, the 16th annual EALE conference in Lisbon, the SFI workshop on Gender in the Workplace, Copenhagen and the 2006 Workshop on Linked Employer-Employee Data, Oslo for their suggestions. Jens Therkelsen and Mette Trier Damgard provided able research assistance on this project.
} 


\section{Introduction}

A growing area of research these days focuses on the reorganization of work taking place in the modern-day organization, away from a task-specialized structure towards a more taskintegrated organizational structure (Lindbeck and Snower, 2000). The new organizational structure has introduced work practices such as job rotation and learning across tasks, teamwork, decentralization of responsibility and worker participation in decision making. The adoption of these new work practices implies a breakdown of traditional occupational barriers and the establishment of flatter organizational structures. Moreover, highperformance work practices are usually accompanied and sustained by performance-based pay, giving rise to new payment schemes.

In terms of their adoption, such practices diffused slowly in the decade of the 1970s and 1980s but began to be widely adopted starting from the early 1990s, and by 1997, approximately $71 \%$ of U.S. firms had adopted some form of innovative human resource management practices (Osterman, 1994; 2000). In Europe considerably fewer employers have implemented these practices; see OECD (1999). However, in Scandinavia, including Denmark, the new practices have been adopted more frequently than in the rest of Europe.

A great deal of the previous research in this area has focused on the effect of new workplace practices on establishment level outcomes such as total labour costs, and firm productivity; see Ichniowski and Shaw (2003) for a recent survey. Relatively less is known about their effects on workers' wages, and in particular, whether these practices affect groups of workers differently. This is largely due to a lack of micro data on workers matched to firmlevel data on the adoption of high-performance work practices. Even when wage outcomes are considered, previous studies have assumed that the returns to these practices do not vary by gender, race or other group characteristics, the typical outcome under study being total labour compensation or average establishment level earnings; exceptions are Bauer and Bender (2003) and Black and Lynch (2004). In this paper, we consider the effects of new work practices separately on men's and women's wages within a firm. Our aim is to investigate whether the new economy can act as the great equalizer - that is, whether the introduction of innovative human resource management practices can reduce the gender gap in wages among men and women working within the same firm. 
There are several channels through which new workplace practices may lower the gender wage gap. First, the breakdown of traditional occupational lines or barriers due to the introduction of quality control circles or job rotation gives women an entry in to the design and production side, traditionally men's domain, and allows for skill accumulation in tasks that are more remunerative than traditionally female tasks. Second, decentralization of supervisory authority and increased worker participation in decision-making give women greater bargaining power and control over wages and working conditions compared to hierarchical organizational structures in which supervisory positions are mostly held by men.

Another mechanism could be that incentive-based pay systems that accompany high performance work practices allow for transparency in pay, as wages are based on known, objective and quantifiable performance criteria. This may make it easier for women to bargain for matching increases or to seek legal recourse in situations where wage discrimination may be present. Further, some of the new practices impart flexibility in workers' schedules, allowing women to balance home and work responsibilities more effectively, thereby raising their productivity at the workplace. Finally, a recent line of experimental enquiry within cognitive and social psychology explores whether women have an enhanced ability to multitask or superior communicative and collaborative skills (Williams et al., 1991; Rubenstein et al., 2001; Hannah and Murachver, 1999; Underwood et al., 1990; 1994). Possessing a relative advantage in such skills could make women better matched to meet the demands of the modern workplace and thereby raise their relative value to employers.

There exist a few channels through which the introduction of new workplace practices could serve to increase the gender gap in pay. Because of family responsibilities, women may find it difficult to make the needed investments to take full advantage of the new practices. For example, work practices that demand flexibility in work schedules i.e. to be "on call" at all times or work non-standard hours may make it even more difficult to balance work life and family life. Also, decentralization of pay negotiation and incentive-based pay remove centrally-determined wage floors which have effectively increased women's wages relative to men's. Yet another factor that can boost men's wages in this context is if (mostly male) supervisors in firms which adopt new working practices are given pay increases by management in exchange for their cooperation in supporting and disseminating these practices within their units (Black and Lynch, 2004), i.e. acting as facilitators. 
The overall effect on the wage gap is theoretically inconclusive and can only be determined by empirical means. Our purpose is therefore to quantify the effect of these practices on the within-firm gender wage gap, controlling for all other observable firm characteristics that can affect wages.

By combining a unique 1999 survey of employers in Denmark to register data on their employees, we match data on a total of 224,262 workers working in 1,387 of the firms that were surveyed. The firms that were surveyed were asked to provide information on the adoption of innovative work practices as well as new incentive-based pay practices. This allows us to estimate the wage impacts of new workplace practices on groups of male and female workers and on the gender wage gap within private sector organisations in Denmark. As new work practices have been implemented in a larger scale and rather differently in the manufacturing sector, we restrict our analysis to the manufacturing sector only. This gives us a sample of 691 firms employing in total on average 194,838 workers per year and 282 employees per firm. This focus also makes our results comparable to previous studies in the literature (Black and Lynch, 2001, 2004 for example).

In spite of the Danish gender wage gap being one of the lowest among industrialised countries, the female-male wage ratio in Denmark has shown signs of stagnation in the 1980s and 1990s at a more or less constant level of $80-88 \%$, depending on whether straight wages or total compensation are used as a measure (see for example Pedersen and Deding, 2002). A number of previous studies have linked women's relatively lower pay to their over-representation in the public sector, which has experienced slower wage growth than the private sector in recent decades (Rosholm and Smith, 1996; Datta Gupta et al., 2000). A few recent studies which have had access to matched data have turned their attention to the private sector, where the raw male-female gap in pay is considerably larger than the national average, even when considering full-time workers only. Further, in the private sector, even within narrowly defined industry and occupation groupings, Datta Gupta and Rothstein (2005) and Deding and Wong (2004) find that a significant unexplained gap exists even after controlling for standard human capital characteristics. Thus, the question is whether implementation of new work practices and new forms of work organization can be a way to eliminate the persistent wage differences that seem to exist among men and women of identical characteristics even within narrowly defined job types. 
The rest of the paper is organized as follows. Section II yields a brief review of the earlier literature. In the next two sections we discuss some methodological issues and describe the data at our disposal. The fifth and the sixth sections give the empirical model and the empirical estimates, respectively. Section VII concludes.

\section{Previous Research}

Only a few previous studies have had access to data on work practices at the individual or firm level. A study on the impact of work practices on productivity by Black and Lynch (2001) estimates production functions using both GMM and within estimator techniques on a representative panel data set of businesses over the period 1987-1993. They find that it is not so much the type of work practice but rather how it is implemented that matters for productivity. For example, productivity is higher in unionized establishments which adopt work practices giving workers greater decision-making authority together with pay practices such as incentive-based pay schemes, than in non-union establishments with the same practices.

Another study on the relationship between workplace innovations and wages by Black and Lynch (2004) matches plant level practices with plant-level productivity and average establishment wages, and estimates production functions and wage functions using both cross-sectional and longitudinal data drawn from surveys of U.S. manufacturing-sector establishments from 1993 and 1996. This study finds that the reorganization of workplaces to incorporate high performance work practices leads to an increase in average establishment wages of about $6 \%$. But, at the same time, profit sharing and/or stock options lead to lower regular pay for workers, particularly technical and clerical/sales workers. Their study is based on a sample size of 766 establishments in 1996 (cross-section) and 193 establishments in the panel (1993-1996).

Cappelli and Neumark (2001) use a national probability sample of establishments that includes comparable measures of performance and work practices across organizations. By virtue of the sample's longitudinal design, they are able to incorporate data stemming from a period preceding the introduction of these practices. This allows them to purge their estimates for firm- or establishment-level heterogeneity that may arise due to high- 
performing firms having a greater ability to adopt such practices ("best practices”). Their findings point to increased employee compensation and therefore higher labour costs per employee from adopting these practices, but weak productivity effects. The overall effect on profitability is inconclusive.

Caroli and van Reenen (2001) study organisational changes, which imply a reduction of hierarchy within work organisations in two separate panels of French and British firms. They find that these changes had a positive impact on productivity. In addition, they find negative effects on unskilled manual workers' employment share and wage sum. Thus, their study indicates that the new work practices were biased against unskilled labour. Bauer and Bender (2003) utilize matched employer-employee data from Germany to study effects of organisational changes and focus in particular on the new practices' effects on firms' wage structures. They find that flattened hierarchies and especially the introduction of teamwork increase wage inequality within firms, due to the wage gains being concentrated at the higher end of the firms' wage distributions.

A paper by Bailey, Berg and Sandy (2001) examines the relationship between high performance work systems (HPWS) and the earnings of 4,000 management employees in 45 establishments in the steel, apparel and medical electronics and imaging industries in the period 1995-97. They find that, except in the case of medical electronics, management workers employed in workplaces in industries that have more high-performance practices do earn more than those in traditional workplaces, after controlling for gender, race, education, experience and tenure. The lack of an effect in the medical industries probably reflects the importance of formal qualifications and education for pay in that industry.

Eriksson (2003) makes use of the same data source as the current paper and examines the effects of introduction of new work practices in Danish firms on firms' average wages and productivity. He distinguishes between practices adopted for salaried employees and those paid by the hour and investigates how their impact differs between early and late adopters as well as between the short- and the medium-term. The study shows that it is crucial to control for the skill structure of firms' workforces. Otherwise the returns to practice adoption are substantially overestimated. Late adopters benefit less while for early adopters the short-run (2-3 years) gains seem to be quite persistent. 
We are aware of only one micro study that examines the question of whether workplace practices can explain a significant part of the gender wage gap. ${ }^{1}$ Drolet (2002) uses matched employer-employee data on 24,302 workers from the 1999 Canadian Workplace and Employee Survey to find that - not controlling for industry and occupation - workplace characteristics account for $27.9 \%$ and worker characteristics for $10.8 \%$ of the pay gap. However, the largest contributor of workplace characteristics is the workplace part-time rate, which alone accounts for $17.7 \%$ of the pay gap. In terms of measures of high-performance workplace practices, Drolet (2002) has access to two measures, whether or not the worker participates in self-directed workgroups and whether or not the worker receives performance-based pay. The contribution of the these practices to the wage gap is however, minor and the largest single factor explaining gender differences in pay between men and women in Canada appears to be industry.

Two recent papers by Garcia et al. (2002) and Lausten (2001) investigate the impact of the degree of worker autonomy and level of authority in explaining gender wage differences among Spanish employees and Danish executives, respectively. None of these previous studies has, however, been able to examine the effect of a wide array of high performance work practices on men's and women's wages for an adequately large sample of establishments spanning a relatively long period. By having access to an unique survey of the extent of adoption of new work practices among firms in Denmark, matched to a large employer-employee data base, ours is the first study to be able to quantify the impact of a number of practices on the wages of male and female employees within firms in the manufacturing sector, controlling for other firm-level characteristics.

\section{Data Description}

The analysis uses a data set on Danish private sector firms with more than 20 employees, which has been constructed by merging information from two sources. The first source is a questionnaire directed at firms that contains information about their work and compensation

\footnotetext{
${ }^{1}$ In Altonji and Blank's (1999) Handbook of Labor Economics chapter on labour market gender differentials, not one of the studies is concerned with the impact of differences and changes in work organizations. The same is also true for new pay practices; for an exception, see Heywood and Jirjahn (2002).
} 
practices. The other is a longitudinal employer-employee data $\operatorname{set}^{2}$ that provides information about firm characteristics and performance as well as about the firms' employees.

The survey represents a unique source of information on Danish firms' internal labour markets and changes therein. In addition to some background information about the firm, each firm was asked about its work organisation, compensation systems, recruitment, internal training practices and how it evaluated its employees. For the questions concerning work design and practices, the firms were asked to differentiate between salaried employees and those paid by the hour. A brief description of the questionnaire and the main results are available (in Danish) in Eriksson (2000).

The survey was administered by Statistics Denmark as a mail questionnaire survey in May and June 1999, which was sent out to 3,200 private sector firms ${ }^{3}$ with more than 20 employees. The firms were chosen from a random sample, stratified according to size (as measured by the number of full time employees) and industry. The survey over-sampled large and medium-sized firms: all firms with 50 employees or more were included, and 35 per cent of firms in the 20-49 employees range. The response rate was 51 per cent, which is relatively high for the rather long and detailed questionnaire of the type that was used. ${ }^{4}$

For the analysis in the present paper we use data from the manufacturing sector only. This is motivated by the fact that the practices may have been implemented quite differently in the services and the manufacturing sectors. The sample we study thus consists of 691 firms and on average 194,838 employees per year. It should be noted that two thirds of male workers are in blue collar jobs compared to about $60 \%$ of female workers, but the difference is not large. Thus, as we distinguish between salaried employees and those paid by the hour, we are not simultaneously distinguishing between the genders.

Using unique firm identification numbers from Statistics Denmark, the survey data were supplemented with information about the firms as well as about their workforces. This

\footnotetext{
${ }^{2}$ See the Centre for Corporate Performance, Aarhus School of Business (www.ccp.asb.dk) for a more detailed description.

${ }^{3}$ Actually the questionnaire was sent to the person in each firm who according to an address list of the Danish Employers Federation is the most relevant one to answer question regarding HRM issues.
} 
information is taken from a large employer-employee linked database, which covers all private sector firms and all the employees who worked in them (in Denmark) in any year during the period 1980 to 2000. ${ }^{5}$ The panel contains detailed information about employee characteristics ${ }^{6}$ (and hence, firms' workforces in any year) and about their labour earnings and other income. In addition, the panel has economic information about firms with 20 or more full-time equivalent employees, for the years 1992 to 2000.

Firms' use of work (and pay) practices can be measured along several dimensions. The measure adopted in the survey questionnaire is whether a firm has implemented one of six work designs:

(i) Self-managed teams. An organisation with self-managed teams gives its members authority over how to perform tasks, or even which tasks to perform. Important aspects of team working are pooling of skills and skills development of individual workers.

(ii) Job rotation. Job rotation is a system where the workers are explicitly required to rotate between different jobs. This increases the variety of tasks to be performed by the employee and is also likely to enhance the employee's understanding of the operation.

(iii) Quality circles. Groups of workers who meet regularly to solve problems concerning productivity and people and to discuss aspects of performance and quality.

(iv) Total quality management (TQM). An important element of TQM programmes, of which ISO9000 probably is the best known, is that they include employee involvement.

(v) Benchmarking. Benchmarking is a formal system of learning about practices in other firms and organisations.

(vi) Project organisation. Groups of workers are organised in projects with defined targets, timetables, budgets and frequently considerable authority with respect to how to perform tasks.

It is important to note that the firms were also asked about when each work practice (if any) was adopted. However, one important piece of information we do not have regarding the

\footnotetext{
${ }^{4}$ The response rates for the size and one-digit industry cells vary only little: between 47 and 53 per cent. Thus, the representativeness of the sample is of no major concern.

5 The important feature of the panel is the link between firms and employees, which is consistent over time. The data originate from two separate registers maintained by Statistics Denmark: the integrated database for labour market research (IDA) and the business statistics database (BSD).

${ }^{6}$ Worker characteristics at the person-year level include gender, age, ongoing tenure, and level and years of education.
} 
implementation of the practices is the proportion of employees affected by the particular work design. Nor were the respondents asked to rank the practices according to some notion of their importance. It seems plausible to assume that the higher the number of practices used, the larger is the proportion of workers in the firm involved in some of the new work practices. Thus, the number of practices adopted can serve as a proxy for the intensity of implementation.

The firms were also asked a corresponding question regarding the implementation of performance related pay (PRP) practices. More precisely the firms were asked whether they had adopted one of four PRP methods - team bonus, individual bonus, stock and stock options and profit sharing - for four different categories of employees: top managers, middle-management, other white collar workers and blue collar workers; see Eriksson (2001), for details. In contrast to the work practices, the firms were unfortunately not asked about when they had implemented the different pay practices. The questionnaire only asked the firms whether they had made considerable changes in their payment systems in recent years, without being more specific as to when or to which payment system.

By year 1999 a little less than every second firm (44.8 per cent) of the firms had implemented at least one of the new work practices. As can be seen from Figure 1, the majority of the firms that had, have adopted one or two practices, whereas adoption of several practices is relatively rare. During the period under study, there has been a considerable rise in the number of adopters, though. In 1991, 80.1 per cent of firms had not implemented one of the new work practices. ${ }^{7}$

Table 1 gives some information on manufacturing firms' adoption of each work practice as of year 1998. Table 2 provides corresponding information regarding new pay practices. From Table 1 we may note that the most widely implemented new work practices are self-managed teams, project organisation and job rotation schemes. Corresponding shares of employees working in firms that have or have not introduced the practices are found in Table 3. As larger firms are substantially more likely to have adopted new work or pay practices (see Eriksson, 2001), the proportion of workers in firms with them is larger than the share of firms that have them.

\footnotetext{
${ }^{7}$ See Eriksson (2001) for further details.
} 
Since the questionnaire was only sent out to private sector firms with 20 or more full-time employees, the (unweighted) average proportion of women in the firms - 31.2 per cent - is considerably lower than in the whole Danish labour force, in which women make up about fifty per cent. It can, moreover, be seen that firms that have adopted new working practices have on average a larger proportion of female employees than other firms.

So, female employees are more likely to work in a firm with one or more of the new work practices. The average firm wage for women is, however, higher in firms which have not adopted the new practices, save firms with quality circles and project organisations where hourly wages are respectively higher and roughly the same as in those without them. For male workers there is a similar pattern, except for firms with and without project organisation and benchmarking, where men are on average paid more in the former. The "raw" firm level gender gap is clearly smaller in firms that have introduced job rotation and TQM schemes than in those that have not.

Turning to Table 2, every second firm has the so called qualification pay system - a formalised wage setting system, where extra pay is given an employee based on her qualifications such as education, experience of a certain job or tasks, skills acquired through on-the-job training, etc. - and 35-40 per cent have team or individual bonuses. We notice that the proportion of women is the same in firms with and without the performance related pay systems, save stock and stock options where there are somewhat more women working in firms that have them. For both genders we observe the following pattern: with the exception of qualification pay and profit sharing, the average wage is higher in firms with the new pay practices than in those which have not introduced them, and the differences are typically quite large. As for the firm gender gaps, they are larger in firms with individualised pay like individual bonus systems and stock and stock option schemes.

Of course, all the wage differences in Tables 1 and 2 may be due to differences in the composition and skills structures of the workforces in firms with and without the new work and pay schemes. In particular, the differentials between adopters and non-adopters of new work and pay practices may reflect the sorting effect mentioned earlier (see Lazear, 2000) that work and pay systems rewarding good performance attract the best workers. The similarity of patterns for both genders also suggests that there are a number of factors we 
have not yet considered that give rise to differences in pay between adopters and nonadopters of different work and pay practices. In the following section we will, therefore, carry out analyses that aim at controlling for these differences as well as accounting for when and which of the different work practices were implemented in the firms.

\section{Empirical Model}

The dependent variable in the analysis is the log of hourly wages, where wages are deflated by the consumer price index. More specifically, we compute for each firm and year, (i) the average hourly wage separately for women and men, and (ii) the gender wage differential. Differences in the average firm wages reflect of course differences in the composition of the firms' workforces with respect to age, education and other human capital variables. However, as the firms' workforce structures typically change only slowly, we do not enter these as explanatory variables in the estimations but capture them by using firm fixed effects and a time trend.

Log hourly wages for sex group $i$ in firm $j$ at time $t$ is given by:

$L o g W_{i j t}=\alpha_{1} S_{i}+\alpha_{2 j} F_{j}+\alpha_{3} T_{t}+\beta_{1 j}\left(S_{i} \times F_{j}\right)+\beta_{2}\left(S_{i} \times T_{t}\right)+\beta_{3 j}\left(F_{j} \times T_{t}\right)+\delta_{i} N W P_{j t}+\varepsilon_{i j t}(1)$

where $S_{i}$ indicates sex group $i, F_{j}$ is an indicator for the firm, $T$ indicates the time period and $N W P_{j t}$ is an indicator for new workplace practices, the dependent variable of interest. Note that the NWP indicator which we will operationalise in alternative ways is a time-varying variable. Thus, the indicator captures the effect of introducing a specific or one additional new work practice in the firm. An advantage of observing firms before they introduce NWP is that we can purge the estimates for some firm-level heterogeneity that arises because of the "best practices" effect.

The gender gap in wages can be written as

$$
\begin{aligned}
& \log W_{m j t}-\log _{f j t}=\alpha_{1}\left(S_{m}-S_{f}\right)+\beta_{1 j}\left(S_{m}-S_{f}\right) F_{j}+\beta_{2}\left(S_{m}-S_{f}\right) T_{t}+\left(\delta_{m}-\delta_{f}\right) N W P_{j t} \\
& +\varepsilon_{m j t}-\varepsilon_{f j t} \\
& \text { or, }
\end{aligned}
$$


$\Delta \log W_{j t}=a+b_{1 j} F_{j}+b_{2} T_{t}+d N W P_{j t}+\varepsilon_{j t}$

The NWP indicator is entered in three different ways. First, we use a simple dummy for whether or not the firm has adopted at least one of the new work practices. This is of course a very crude measure. Our second measure is the number of new work practices, which informs us about the marginal effect of additional work practices. This measure allows for synergies arising from bundling practices together, without either arbitrarily grouping practices ex ante or selecting those groupings that best fit the data ex post. The number of practices also serves as a proxy for the intensity of coverage as it is typically the case that the higher the number of practices that are implemented, the larger is the proportion of workers in the firm who are covered. The third operationalization is entering the work practices individually. We run the equations separately for women's wages, men's wages and the gender differential. A small number of the firms have either very few (less than 5) male or female employees, and for these observations the firm gender wage gap measure is rather meaningless. We have therefore, omitted the firms with less than five male or female employees from the estimation sample.

\section{Methodological Issues}

A few methodological issues present themselves in the estimation of wage models accounting for new workplace practices. First, more productive workers may self-select into jobs characterized by high-performance work practices or where pay is tied to performance (see for example Parent, 1999; Lazear, 2000). The question is, how to disentangle this "sorting” effect from real productivity/rent-sharing effects of work and pay practices? This issue cannot be resolved easily in our data set-up. This is because it is difficult to find unique instruments that can explain workers' choices of firms but do not also affect their wages.

The other selection issue is that firms that face the threat of closure may be the ones most likely to adopt such practices. Thus, there is a need to measure performance before these practices are introduced, (see for example Cappelli and Neumark, 2001). As the sample period in the current analysis spans the period 1992 to 2000, and as only a fifth of the firms 
had adopted a practice already in the 1980s, a relatively large number of firms in the sample are observed before the adoption of such practices, allowing us to control for this type of heterogeneity.

As the model we will estimate is in essence a difference-in-differences (DID) estimation, another potentially serious concern is that of serial correlation. This is because firstly, the panel is fairly long, secondly, wages, the dependent variable may be serially correlated and thirdly, the treatment variable (introduction of new work practices) may not change much over time. Bertrand, Duflo and Mullainathan (2004) suggest a technique that can eliminate this problem which works well as long as there is an adequate count of the unit of observation (firms, in our case) in the data.

That is, we first regress wages on firm fixed effects and a time trend. Second, the residuals for only the treated firms (those that implemented the practices) are divided into pre and post-treatment periods, reducing the data set to a two-period panel. Then, a simple fixed effects regression of an "after" dummy on wages is run on the transformed data, yielding the serial-correlation corrected estimate and standard error. ${ }^{8}$

\section{Estimation Results}

Let us to begin with consider the simplest version of the NWP indicator: at least one practice, the estimates of which are collected in Table 4. We can see that that these are positive and significant for men, a 1 per cent rise, and negative and significant for women (1 per cent fall) so that the gender wage gap increases by 2 per cent. As the wage gains for the hourly paid are of opposite signs, the gender differential is affected, and to the disadvantage of female employees, by the introduction of new work practices, measured in this admittedly very crude manner. For salaried employees, the gender wage gap is unaffected.

Turning next to Table 5, where the number of practices is used as the NWP indicator, we may observe that the firm average wage for all (hourly paid) men is positively affected by the first two (three) practices, after which most of the estimates do not differ significantly from zero. It should be noted that the estimates for five practices, some of which carry large 
coefficients, are based on very few observations. The wage of female workers is significantly lower in firms that have implemented one to four new work practices. However, when separating between salaried female employees and those paid by the hour, almost all coefficients lose their statistical significance. The firm level gender gap estimates are positive for the first 3-4 practices adopted, and this seems to be due chiefly to the increase in the gender gap among the hourly workers.

Note, however, that in addition to the rent sharing interpretation, it is also possible to interpret the results in Tables 4 and 5 (as well as subsequent tables) as a market outcome. If female employees have a stronger preference for the new, less hierarchical, work organizations allowing for more collaboration than men, then the gender gap observed could be due to compensating wage differentials: women pay for the flatter more cooperative workplaces (whilst men are compensated for it).

Table 6 gathers the results from regressions with all the individual practices included. For women the estimates are either insignificant (for the salaried, all practices) or with one exception - a large positive coefficient attached to quality circles for employees paid by the hour - negative. For men, more coefficients differ from zero. These are positive, save job rotation for men paid by the hour and project organisation for salaried men. Hence in many cases the "net effect" on the firm level gender wage gap is positive, that is, the work practice is associated with a large gender wage differential. For the salaried employees the impact of the practices on the gender gap is small and differs from zero only for project organisation. In all cases where the gender gap is significantly larger in firms that have adopted a work practice, the coefficient for the practice in question in the wage equations for women is always significantly (or not so far from significantly) negative.

Because the results for the number of practices indicate that bundles might matter, we have also run some specifications including interactions between individual practices. These are presented in Table A-1 in the appendix. They show that in only one case does the interaction term differ significantly from zero: when a firm has quality circles, TQM and job rotation schemes. Moreover, the main effects remain largely unaltered. Thus, interacting practices

\footnotetext{
${ }^{8}$ We also estimated the models without corrections for serial correlation. The estimates did not differ much from those reported in the text.
} 
adds little to our understanding of how wage differences between firms are affected by changes in work practices.

Thus, we find very little, and mixed, evidence that new work practices improve women's access to skill acquisition. For women paid by the hour, quality circles are associated with a large wage premium and a small gender gap, but on the other hand job rotation schemes leave their wage unchanged both in absolute terms and relative to men. Nor is there much to suggest that the new practices improve female employees' bargaining power. TQM and project organisations (for salaried workers) are associated with a smaller gender gap, but this is due to men obtaining lower pay in firms which have these practices.

In Tables $A-2$ to $A-4$ in the appendix, we present the results from regressions in which individual practices are entered one by one. Somewhat surprisingly the results do not differ from those in Table 6. In fact they are very similar regarding significance and do not differ markedly when it comes to magnitudes, either. Thus, the estimates from including the practices separately one at a time into equation (1) yield some additional support to our earlier findings, insofar as the introduction of new work practices in firms widens the gender wage gap for workers paid by the hour, but leaves it largely unchanged for the salaried workers.

Assuming the gender pay differential associated with the new work practices is not merely due to compensating wage differentials, where does it come from? One possibility is that it could be due to differential sorting. Because of the lack of a counterfactual, we can unfortunately not apply the DID analysis to newcomers and incumbents, respectively, which otherwise would be the obvious way to investigate the role of sorting. Instead we have estimated wage growth equations for the employees in firms that implemented a new work practice during years 1990-95 distinguishing between newcomers and incumbents. ${ }^{9}$ The observations on the individuals' wage growth are from two and more years after the practice was adopted. Controlling for the employees' age, education and job level and the size and industry of the firm, we find that neither male nor female newcomers receive significantly higher wages. This we interpret as implying that the quality of the new workers joining firms after they introduced the new work practice did not increase.

\footnotetext{
${ }^{9}$ To save space these are not reported here, but are available from the authors upon request.
} 
Another possibility is that the increased gap reflects real differences in productivity due to women having fewer possibilities to exploit the advantages of the new work organizations because of family responsibilities. In order to shed some light on this we computed average firm wages for the genders by presence of children under the age of 7 and 18, respectively. We found only small differences; the gender gap for all employees was 32.61 Danish Kroner (about 4.40 Euros), and 33.49 (4.50 Euros) and 33.09 (4.45 Euros) for those with children under the age of 7 and 18, respectively. Thus, family responsibilities do not seem to be a prime candidate for explaining the larger gender gap associated with the new work practices. Still another explanation could be the facilitator hypothesis mentioned by Black and Lynch (2004): male supervisors are rewarded for supporting and implementing the new practices in their workplaces. The data do not speak in the favour of this hypothesis, either. First, the proportion of men in the middle management positions is roughly the same in firm with and without new work practices: 14.1 and 16.2 per cent, respectively. Second, as we have seen above, the gender gap for salaried workers is not larger in firms that have adopted the new practices.

\section{Conclusions}

We have investigated the effect of new workplace practices on the gender wage gap by combining information on the adoption of an array of workplace practices obtained from a unique survey on firms matched to panel data on the population of workers within these firms. Thus, this is one of few studies to explore whether such practices impact groups of workers within firms differently, in contrast to the previous literature that is largely focused on establishment-wide earnings outcomes. Our question is whether or not new work practices can be the great equalizer when it comes to the persistent pay gap that exists between men and women who have the same characteristics and who work in the same firms.

The descriptive evidence shows that the most widely implemented work practices among manufacturing firms in the private sector in Denmark are self-managed teams, project organisation and job rotation schemes. Estimation of a difference-in-differences model of wages and work practices controlling for all observed firm-specific factors shows that wage gains from the introduction of new workplace practices seem to accrue mainly to men, and in 
fact, wage losses accrue to women so that the gender gap in pay widens at the level of the firm, in particular among hourly-paid workers.

When considering individual work practices, essentially the same findings obtain despite the "unbundling” of practices that presumably belong together: the pay gap widens significantly for workers paid by the hour, particularly in firms which introduce teamwork and benchmarking. It is only reduced in the case of quality circles. For salaried employees the pay gap remains unchanged in most cases, although it is reduced significantly through project organisation. These findings indicate that female salaried employees benefit particularly from the greater control over task definition and planning implied by project organization and female workers paid by the hour are able to learn across tasks by participating in quality control circles, and these factors raise their relative wages. But these represent the exception rather than the rule. All in all, in most instances men's wages increase and women's wages are reduced in firms that offer these practices. When both groups get increases, then men obtain a relatively larger increase. Bias due to serial correlation does not move the results as nearly identical estimates are obtained after correcting for this problem.

Some additional analyses of the data indicate that the positive effects on men's wages are not a result of worker sorting. Nor do they seem to be due to women having fewer possibilities to exploit potential gains from the practices because of family responsibilities. Whatever the interpretation however, we find that the new economy is not the great equalizer - new workplace practices in most cases benefit men and not women. 


\section{References}

Altonji J.G. and R. M. Blank (1999), 'Race and Gender in the Labor Market', in O. Ashenfelter and D. Card, eds., Handbook of in Labor Economics, Volume 3. Amsterdam: Elsevier, 3143-3259.

Bailey, T., P. Berg and C. Sandy (2001), 'The Effect of High-Performance Work Practices on Employee Earnings in the Steel, Apparel and Medical Electronics and Imaging Industries.’ Industrial and Labor Relations Review, 54, 525-543.

Bauer, T. and S. Bender (2003), Flexible Work Systems and the Structure of Wages: Evidence from Matched Employer-Employee Data. IZA discussion paper No. 353

Bertrand, M., E. Duflo and S. Mullainathan (2004), How Much Should We Trust Differences-in-Differences Estimates? Quarterly Journal of Economics, 119, 249-75.

Black, S.E. and L. Lynch (2001), 'How to Compete: the Impact of Workplace Practices and Information Technology on Productivity', Review of Economics and Statistics, 83, 434-445.

Black, S.E. and L. Lynch (2004), 'What's Driving the New Economy: The Benefits of Workplace Innovation’, Economic Journal, 114, F97-F116.

Cappelli, P. and D. Neumark (2001), 'Do “High-Performance” Work Practices Improve Establishment-level Outcomes', Industrial and Labor Relations Review, 2001, 54, 737-775

Caroli, E. and J. van Reenen (2001), 'Skill Biased Organizational Change? Evidence from a Panel of British and French Establishments', Quarterly Journal of Economics, 116, 14491492

Datta Gupta, N., R.L. Oaxaca, and N. Smith (2000), 'The Danish Gender Wage Gap and Wage Determination in the Public and Private Sectors', in S. Gustafsson and D. Meulders (eds.), Gender and the Labour Market: Econometric Evidence on Obstacles in Achieving Gender Equality, AEA Macmillan Series, 53-74

Datta Gupta, N, R.L. Oaxaca, and N. Smith (2006), 'Swimming Upstream, Floating Downstream: Comparing Women's Relative Wage Progress in the U.S. and Denmark', Industrial and Labor Relations Review, Vol. 59, No. 2 (Jan), pp. 243-266..

Datta Gupta, N. and Rothstein, D. (2005), 'The Impact of Worker and Establishment-level Characteristics on Male-Female Wage Differentials: Evidence from Danish Matched Employer-Employee Data', Labour: Review of Labour Economics and Industrial Relations, Vol 19(1), pp. 1-34.

Deding, M. and K. Wong (2004), 'Mænds og kvinders løn - En analyse af løngabet 19972001', the Danish National Institute of Social Research report 04:10.

Drolet, M. (2002), Can the Workplace Explain Canadian Gender Pay Differentials? Paper presented at the NZ Conference on Database Integration and Linked Employer-Employee Data in Wellington 
Eriksson, T. (2001), 'How Common Are the New Compensation and Work Practices and Who Adopts Them?', Working Paper 01-8, Aarhus School of Business.

Eriksson, T. (2003), 'The Effects of New Work Practices: Evidence from EmployerEmployee Data.' in T. Kato and J. Pliskin, eds., The Determinants of the Incidence and the Effects of Participatory Organizations. Advances in the Economic Analysis of Participatory and Labor-Managed Firms, Vol. 7. Amsterdam: Elsevier, 3-30.

Garcia, J., P. J. Hernández, and A. López (2002), ’An Investigation of the Relationship between Job Characteristics and the Gender Wage Gap', unpublished working paper, May 2002.

Hannah, A. and T. Murachver (1999), 'Gender and Conversational Style as predictors of Conversational Behavior', Journal of Language and Social Psychology, 18, 153-175.

Heywood, J. and U. Jirjahn (2002), 'Payment Schemes and Gender in Germany', Industrial and Labor Relations Review, 56, 44-64

Ichinowski, C. and K. Shaw (2003), 'Beyond Incentive Pay: Insiders' Estimates of the Value of Complementary Human Resource Management Practices', Journal of Economic Perspectives, 17 (1), 155-178

Lausten, M. (2001), Gender Differences in Managerial Compensation - Evidences from Denmark. Aarhus School of Business Department of Economics working paper no 01-4.

Lazear, E. (2000), 'Performance Pay and Productivity', American Economic Review, 90, 1346-1361.

Lindbeck, A. and D. J. Snower (2000), 'Multi-task Learning and Reorganization of Work: From Tayloristic to Holistic Organization', Journal of Labor Economics, 18, Number 3, 2000, 353-376

OECD (1999), ‘Employment Outlook’ (OECD, Paris)

Osterman, P. (1994), 'How Common is Workplace Transformation and Who Adopts It?', Industrial and Labor Relations Review, 47, 173-188

Osterman, P. (2000), 'Work Reorganization in an Era of Restructuring: Diffusion and Effects on Employee Welfare’, Industrial and Labor Relations Review, 53, 179-96.

Parent, D. (1999), 'Methods of Pay and Earnings: A Longitudinal Analysis', Industrial and Labor Relations Review, 53, 71-86.

Pedersen, L. and M. Deding (2002), 'Wage Differentials between Women and Men in Denmark', the Danish National Institute of Social Research, Working Paper 15:2002.

Rosholm, M. and N. Smith 1996, 'The Danish Gender Wage Gap in the 1980s: A Panel Data Study', Oxford Economic Papers, 48, 254-279. 
Rubenstein, J., D. E. Meyer, and J. E. Evans (2001), 'Executive Control in Cognitive Processes in Task Switching', Journal of Experimental Psychology - Human Perception and Performance, 27, 763-797.

Underwood, C., N. Jindal, and J. Underwood (1994), 'Gender Differences and Effects of Cooperation in a Computer-based Task.' Educational Research, 36, 63-74.

Underwood, C., M. McCaffrey, and J. Underwood (1990), 'Gender Differences in a Cooperative Computer-based Task’, Educational Research, 32, 44-49.

Williams, C. L., and W. H. Meck (1991), 'Organizational Effects of Gonadal Steroids on Sexually Dimorphic Spatial Ability’, Psychoneuroendocrinology, 16, 157-177. 
Figure 1. Firms' adoption of new work practices in 1999

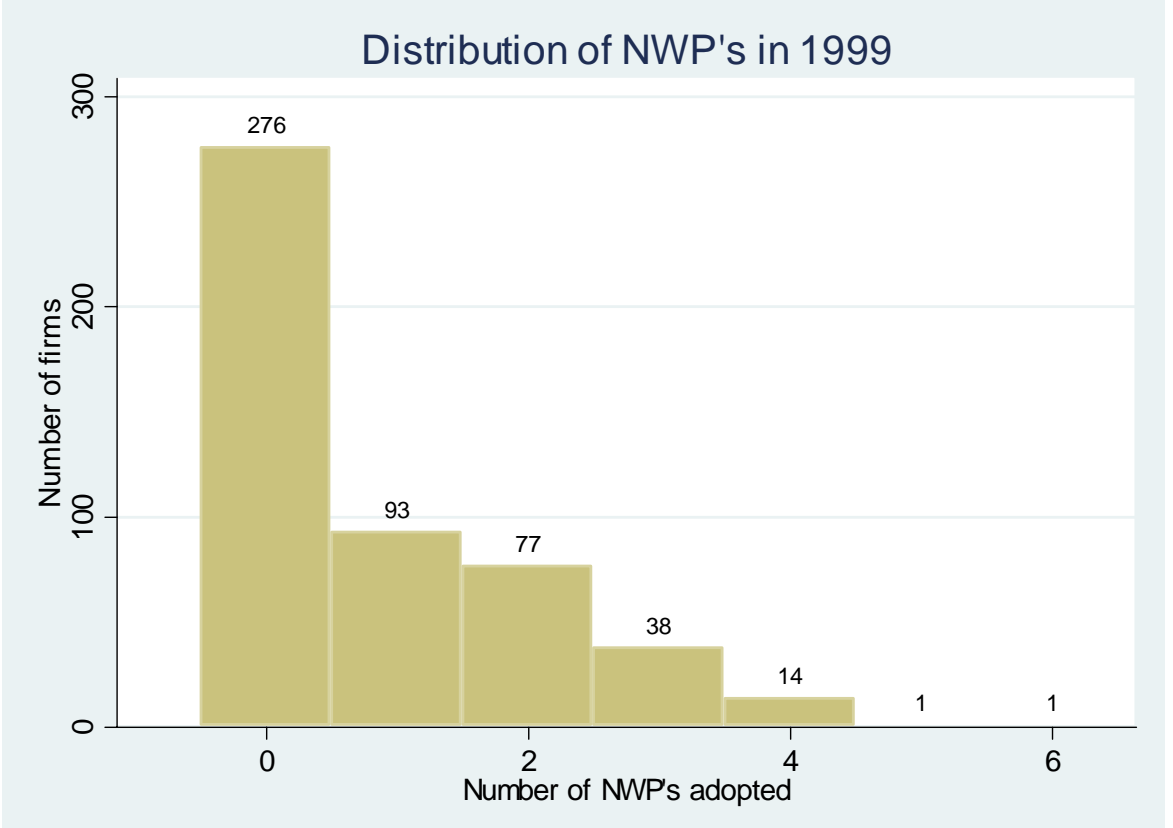


Table 1. Some characteristics of adopters and non-adopters of new work practices.

\begin{tabular}{|c|c|c|c|c|c|c|}
\hline Work practice: & Teams & Teams & Job rot. & Job rot. & Q. circles & Q. circles \\
\hline Has adopted: & NO & YES & $\mathrm{NO}$ & YES & NO & YES \\
\hline Prop. of firms & 82.2 & 17.8 & 84.95 & 15.05 & 97.5 & 2.5 \\
\hline Prop. of women in firm & 31.6 & 31.8 & 30.7 & 36.7 & 31.6 & 34.4 \\
\hline $\begin{array}{l}\text { Av. hourly wage } \\
\text { women }\end{array}$ & 117.32 & 116.46 & 117.34 & 116.21 & 117.12 & 119.27 \\
\hline Av. hourly wage men & 149.93 & 149.07 & 150.36 & 146.49 & 149.70 & 152.76 \\
\hline Raw gender gap & 32.60 & 32.62 & 33.02 & 30.28 & 32.58 & 33.49 \\
\hline Work practice: & TQM & TQM & Proj.org. & Proj. org. & Benchmk. & Benchmk. \\
\hline Has adopted: & NO & YES & NO & YES & NO & YES \\
\hline Prop. of firms & 95.8 & 4.2 & 86.5 & 13.5 & 97.8 & 2.2 \\
\hline Prop. of women in firm & 31.5 & 34.7 & 31.9 & 30.1 & 31.6 & 34.5 \\
\hline $\begin{array}{l}\text { Av. hourly wage } \\
\text { women (DKK) }\end{array}$ & 117.21 & 116.23 & 117.05 & 117.96 & 117.05 & 112.30 \\
\hline $\begin{array}{l}\text { Av. hourly wage men } \\
\text { (DKK) }\end{array}$ & 149.94 & 145.98 & 148.95 & 155.03 & 149.65 & 155.29 \\
\hline Raw gender gap & 32.73 & 29.75 & 31.91 & 32.61 & 32.60 & 32.99 \\
\hline
\end{tabular}


Table 2. Some characteristics of adopters and non-adopters of new pay practices.

\begin{tabular}{|c|c|c|c|c|c|c|c|c|c|c|}
\hline Pay practice: & $\begin{array}{l}\text { Team } \\
\text { bonus }\end{array}$ & $\begin{array}{l}\text { Team } \\
\text { Bonus }\end{array}$ & $\begin{array}{c}\text { Individ. } \\
\text { bonus }\end{array}$ & $\begin{array}{c}\text { Individ. } \\
\text { bonus }\end{array}$ & $\begin{array}{c}\text { Stock } \\
\text { options }\end{array}$ & $\begin{array}{c}\text { Stock } \\
\text { options }\end{array}$ & $\begin{array}{c}\text { Profit } \\
\text { sharing }\end{array}$ & $\begin{array}{c}\text { Profit } \\
\text { sharing }\end{array}$ & $\begin{array}{c}\text { Qualific. } \\
\text { pay }\end{array}$ & $\begin{array}{c}\text { Qualific. } \\
\text { pay }\end{array}$ \\
\hline Prop. of firms & 65.1 & 34.9 & 59.0 & 41.0 & 90.8 & 9.2 & 83.0 & 17.0 & 47.0 & 53.0 \\
\hline $\begin{array}{l}\text { Prop. Of women in } \\
\text { firm }\end{array}$ & 31.6 & 31.7 & 32.0 & 31.1 & 31.3 & 34.6 & 31.6 & 31.8 & 31.8 & 31.5 \\
\hline $\begin{array}{l}\text { Av. hourly wage men } \\
\text { (DKK) }\end{array}$ & 149.95 & 149.68 & 147.80 & 152.61 & 148.16 & 162.75 & 150.29 & 147.27 & 150.91 & 148.77 \\
\hline Raw gender gap & 32.76 & 32.32 & 31.65 & 33.98 & 31.79 & 40.70 & 32.61 & 32.59 & 33.20 & 32.08 \\
\hline
\end{tabular}


Table 3. The share of male and female employees working in firms with new work and pay practices, by practice.

\begin{tabular}{lcc}
\hline $\begin{array}{l}\text { Percentage of employees } \\
\text { in firms with: }\end{array}$ & Female & Male \\
\hline New Work Practices: & 21.8 & 19.5 \\
Teams & 29.5 & 24.1 \\
Job rotation & 9.6 & 7.8 \\
Quality circles & 10.4 & 9.4 \\
TQM & 7.8 & 6.6 \\
Benchmarking & 16.6 & 17.0 \\
Project organisation & & \\
New Pay Practices: & 47.9 & 41.9 \\
Team bonus & 53.8 & 51.9 \\
Individual bonus & 16.6 & 15.9 \\
Profit sharing & 22.8 & 15.2 \\
Stock, stock options & 60.6 & 58.9 \\
Qualification pay & & \\
\hline
\end{tabular}


Table 4. The impact of the adoption of new workplace practices on men's and women's wages, with correction for serial correlation. ${ }^{\text {a }}$ Dependent variable: log hourly wage (in gender gap regressions: difference in log hourly wage)

\begin{tabular}{lccccccccc}
\hline & & \multicolumn{9}{c}{$\begin{array}{c}\text { Gender } \\
\text { Wen, } \\
\text { hourly } \\
\end{array}$} & Men & Women & $\begin{array}{c}\text { Gender } \\
\text { hourly } \\
\text { paid }\end{array}$ & $\begin{array}{c}\text { gap, } \\
\text { hourly } \\
\text { paid }\end{array}$ & $\begin{array}{c}\text { Men, } \\
\text { salaried }\end{array}$ & $\begin{array}{c}\text { Women } \\
\text { salaried }\end{array}$ & $\begin{array}{c}\text { Gender } \\
\text { salaried }\end{array}$ \\
\hline st least one NWP & $0.010^{* *}$ & $-0.010^{* *}$ & $0.020^{* * *}$ & 0.005 & -0.006 & 0.011 & 0.014 & 0.010 & -0.006 \\
& $(0.005)$ & $(0.006)$ & $(0.005)$ & $(0.006)$ & $(0.009)$ & $(0.008)$ & $(0.008)$ & $(0.007)$ & $(0.009)$
\end{tabular}

$\begin{array}{llllllllll}\text { N of obs. } & 1306 & 1306 & 1306 & 1306 & 1306 & 1306 & 1306 & 1306 & 1306 \\ \text { F (1,1304) } & 4.43 & 4.11 & 16.51 & 1.70 & 0.59 & 2.94 & 2.34 & 1.20 & 0.20\end{array}$

\footnotetext{
${ }^{\mathrm{a}}$ The second step was estimated by weighted least squares. F irm fixed effects and a time trend were included as additional controls.
} 
Table 5. The impact of the number of new work practices on firm average wage by gender and the gender gap ${ }^{\mathrm{a}}$

\begin{tabular}{|c|c|c|c|c|c|c|c|c|c|}
\hline $\begin{array}{l}\text { Number } \\
\text { of practices }\end{array}$ & Men & Women & $\begin{array}{l}\text { Gender } \\
\text { Gap }\end{array}$ & $\begin{array}{l}\text { Men, } \\
\text { hourly } \\
\text { paid }\end{array}$ & $\begin{array}{l}\text { Women } \\
\text { hourly } \\
\text { paid }\end{array}$ & $\begin{array}{l}\text { Gender } \\
\text { gap, } \\
\text { hourly } \\
\text { paid }\end{array}$ & $\begin{array}{l}\text { Men, } \\
\text { salaried }\end{array}$ & $\begin{array}{l}\text { Women, } \\
\text { salaried }\end{array}$ & $\begin{array}{l}\text { Gender } \\
\text { gap, } \\
\text { salaried }\end{array}$ \\
\hline \multirow[t]{2}{*}{ One } & $0.015 * *$ & $-0.015^{* *}$ & $0.031 * * *$ & $0.012^{*}$ & -0.011 & $0.023^{* *}$ & $0.021^{* *}$ & 0.009 & 0.013 \\
\hline & $(0.006)$ & $(0.007)$ & $(0.007)$ & $(0.007)$ & $(0.010)$ & $(0.011)$ & $(0.011)$ & $(0.011)$ & $(0.014)$ \\
\hline \multirow[t]{2}{*}{ Two } & $0.015^{*}$ & $-0.019 * *$ & $0.034 * * *$ & -0.003 & -0.004 & 0.001 & 0.006 & 0.013 & -0.007 \\
\hline & $(0.008)$ & (0.009) & $(0.010)$ & $(0.009)$ & $(0.014)$ & $(0.014)$ & $(0.014)$ & $(0.014)$ & $(0.018)$ \\
\hline \multirow[t]{2}{*}{ Three } & 0.015 & -0.012 & $0.027 * *$ & $0.044 * * *$ & -0.007 & $0.051 * * *$ & 0.013 & $0.033^{*}$ & -0.020 \\
\hline & $(0.011)$ & $(0.013)$ & $(0.013)$ & $(0.013)$ & (0.019) & $(0.020)$ & (0.019) & $(0.019)$ & $(0.025)$ \\
\hline \multirow[t]{2}{*}{ Four } & 0.019 & $-0.041^{* *}$ & $0.060 * * *$ & 0.022 & 0.017 & 0.005 & 0.034 & 0.003 & 0.031 \\
\hline & $(0.017)$ & $(0.020)$ & $(0.021)$ & $(0.020)$ & $(0.030)$ & $(0.031)$ & $(0.030)$ & $(0.030)$ & (0.039) \\
\hline \multirow[t]{2}{*}{ Five } & $-0.081^{*}$ & $-0.181 * * *$ & $0.101^{*}$ & $0.132 * *$ & 0.035 & 0.097 & $-0.238 * * *$ & $-0.218 * * *$ & -0.020 \\
\hline & $(0.048)$ & $(0.055)$ & $(0.059)$ & $(0.057)$ & $(0.083)$ & $(0.086)$ & $(0.085)$ & $(0.084)$ & $(0.110)$ \\
\hline \multirow[t]{2}{*}{ Six } & 0.017 & -0.095 & 0.113 & 0.042 & -0.030 & 0.072 & -0.003 & -0.014 & 0.010 \\
\hline & $(0.057)$ & $(0.066)$ & $(0.070)$ & $(0.068)$ & (0.099) & $(0.104)$ & $(0.102)$ & $(0.101)$ & $(0.132)$ \\
\hline N of obs. & 5171 & 5171 & 5171 & 5171 & 5171 & 5171 & 5171 & 5171 & 5168 \\
\hline Adj. $\mathbf{R}^{2}$ & 0.774 & 0.588 & 0.562 & 0.656 & 0.423 & 0.373 & 0.476 & 0.476 & 0.331 \\
\hline
\end{tabular}

${ }^{\mathrm{a}}$ Firm fixed effects and a time trend were included as additional controls. 
Table 6. The impact of work practices considered jointly on firm average wage by gender and the gender gap ${ }^{\mathrm{a}}$

\begin{tabular}{|c|c|c|c|c|c|c|c|c|c|}
\hline & Men & Women & $\begin{array}{l}\text { Gender } \\
\text { gap }\end{array}$ & $\begin{array}{c}\text { Men, } \\
\text { hourly } \\
\text { paid }\end{array}$ & $\begin{array}{c}\text { Women } \\
\text { hourly } \\
\text { paid }\end{array}$ & $\begin{array}{l}\text { Gender } \\
\text { gap, } \\
\text { hourly } \\
\text { paid }\end{array}$ & $\begin{array}{c}\text { Men, } \\
\text { salaried }\end{array}$ & $\begin{array}{l}\text { Women, } \\
\text { salaried }\end{array}$ & $\begin{array}{l}\text { Gender } \\
\text { gap, } \\
\text { salaried }\end{array}$ \\
\hline \multirow[t]{2}{*}{ Teams } & $0.017 * * *$ & $-0.013^{*}$ & $0.030 * * *$ & $0.021^{* * *}$ & -0.009 & $0.030^{* *}$ & $0.022^{*}$ & -0.001 & 0.023 \\
\hline & $(0.006)$ & $(0.008)$ & $(0.008)$ & $(0.008)$ & $(0.011)$ & $(0.012)$ & $(0.012)$ & $(0.011)$ & $(0.015)$ \\
\hline \multirow[t]{2}{*}{ Job rotation } & -0.001 & $-0.020 * *$ & $0.019 * *$ & $-0.027 * * *$ & $-0.025 *$ & -0.002 & $0.031 * *$ & 0.021 & 0.011 \\
\hline & $(0.007)$ & $(0.009)$ & $(0.009)$ & (0.009) & $(0.013)$ & $(0.013)$ & $(0.013)$ & $(0.013)$ & $(0.017)$ \\
\hline \multirow[t]{2}{*}{ Quality circles } & 0.001 & 0.017 & -0.016 & $0.037 *$ & $0.167 * * *$ & $-0.130 * * *$ & -0.007 & -0.023 & 0.015 \\
\hline & $(0.018)$ & $(0.021)$ & $(0.022)$ & $(0.021)$ & $(0.031)$ & $(0.033)$ & $(0.032)$ & $(0.032)$ & $(0.042)$ \\
\hline \multirow[t]{2}{*}{ TQM } & $-0.035 * * *$ & -0.007 & $-0.028 *$ & 0.014 & 0.021 & -0.007 & -0.014 & -0.006 & -0.008 \\
\hline & $(0.013)$ & $(0.016)$ & $(0.017)$ & $(0.016)$ & $(0.023)$ & $(0.024)$ & $(0.024)$ & $(0.024)$ & $(0.031)$ \\
\hline \multirow[t]{2}{*}{ Benchmarking } & 0.000 & -0.011 & 0.011 & 0.010 & -0.030 & $0.039 *$ & 0.007 & 0.012 & -0.006 \\
\hline & $(0.013)$ & $(0.015)$ & $(0.016)$ & $(0.015)$ & $(0.022)$ & $(0.023)$ & $(0.023)$ & $(0.022)$ & $(0.029)$ \\
\hline \multirow[t]{2}{*}{ Project Org. } & 0.012 & 0.007 & 0.006 & $0.021^{* *}$ & 0.011 & 0.010 & $-0.052 * * *$ & 0.000 & $-0.053^{* * *}$ \\
\hline & $(0.008)$ & $(0.009)$ & $(0.010)$ & $(0.010)$ & $(0.014)$ & $(0.015)$ & $(0.014)$ & $(0.014)$ & $(0.019)$ \\
\hline $\mathbf{N}$ of obs. & 5171 & 5171 & 5171 & 5171 & 5171 & 5171 & 5171 & 5171 & 5168 \\
\hline Adj. $\mathbf{R}^{2}$ & 0.774 & 0.588 & 0.562 & 0.657 & 0.427 & 0.375 & 0.477 & 0.475 & 0.332 \\
\hline
\end{tabular}

${ }^{\mathrm{a}}$ Firm fixed effects and a time trend were included as additional controls. 


\begin{tabular}{|c|c|c|c|c|c|c|c|c|c|}
\hline $\begin{array}{l}\text { Number } \\
\text { of } \\
\text { practices }\end{array}$ & Males & Females & $\begin{array}{l}\text { Gender } \\
\text { gap }\end{array}$ & $\begin{array}{l}\text { Males, } \\
\text { hourly } \\
\text { paid }\end{array}$ & $\begin{array}{l}\text { Females } \\
\text { hourly } \\
\text { paid }\end{array}$ & $\begin{array}{l}\text { Gender } \\
\text { gap, } \\
\text { hourly } \\
\text { paid }\end{array}$ & $\begin{array}{l}\text { Males, } \\
\text { salaried }\end{array}$ & $\begin{array}{l}\text { Females } \\
\text { salaried }\end{array}$ & $\begin{array}{l}\text { Gender } \\
\text { gap, } \\
\text { salaried }\end{array}$ \\
\hline Teams & $\begin{array}{l}0.017^{\star \star} \\
(0.007)\end{array}$ & $\begin{array}{c}(-) 0.012 \\
(0.009)\end{array}$ & $\begin{array}{c}0.029^{\star \star \star *} \\
(0.009)\end{array}$ & $\begin{array}{l}0.023^{\star *} \\
(0.009)\end{array}$ & $\begin{array}{c}(-) 0.006 \\
(0.013)\end{array}$ & $\begin{array}{l}0.030^{\star *} \\
(0.014)\end{array}$ & $\begin{array}{c}0.018 \\
(0.013)\end{array}$ & $\begin{array}{c}(-) 0.002 \\
(0.013)\end{array}$ & $\begin{array}{c}0.020 \\
(0.017)\end{array}$ \\
\hline $\begin{array}{l}\text { Job } \\
\text { rotation }\end{array}$ & $\begin{array}{c}(-) 0.003 \\
(0.008)\end{array}$ & $\begin{array}{c}(-) 0.024^{\star *} \\
(0.010)\end{array}$ & $\begin{array}{l}0.021^{\star *} \\
(0.010)\end{array}$ & $\begin{array}{c}(-) 0.027^{* \star *} \\
(0.010)\end{array}$ & $\begin{array}{c}(-) 0.024^{*} \\
(0.015)\end{array}$ & $\begin{array}{c}(-) 0.003 \\
(0.015) \\
(-\end{array}$ & $\begin{array}{c}0.021 \\
(0.015)\end{array}$ & $\begin{array}{c}0.016 \\
(0.015)\end{array}$ & $\begin{array}{c}0.004 \\
(0.019)\end{array}$ \\
\hline $\begin{array}{l}\text { Quality } \\
\text { circles }\end{array}$ & $\begin{array}{c}0.011 \\
(0.019)\end{array}$ & $\begin{array}{l}0.042^{*} \\
(0.023)\end{array}$ & $\begin{array}{l}(-) 0.031 \\
(0.024)\end{array}$ & $\begin{array}{l}0.049^{* *} \\
(0.023)\end{array}$ & $\begin{array}{c}0.180^{* \star *} \\
(0.034)\end{array}$ & $\begin{array}{c}0.131^{* * *} \\
(0.035)\end{array}$ & $\begin{array}{c}0.021 \\
(0.035)\end{array}$ & $\begin{array}{c}(-) 0.009 \\
(0.034)\end{array}$ & $\begin{array}{c}0.030 \\
(0.045)\end{array}$ \\
\hline TQM & $\begin{array}{c}(-) 0.024^{\star} \\
(0.014)\end{array}$ & $\begin{array}{c}0.017 \\
(0.017)\end{array}$ & $\begin{array}{c}(-) 0.041^{* *} \\
(0.018)\end{array}$ & $\begin{array}{c}0.021 \\
(0.017)\end{array}$ & $\begin{array}{c}0.022 \\
(0.025)\end{array}$ & $\begin{array}{c}(-) 0.001 \\
(0.026)\end{array}$ & $\begin{array}{c}0.010 \\
(0.025)\end{array}$ & $\begin{array}{c}0.012 \\
(0.025)\end{array}$ & $\begin{array}{l}(-) 0.002 \\
(0.033)\end{array}$ \\
\hline Benchmarking & $\begin{array}{c}(-) 0.001 \\
(0.013)\end{array}$ & $\begin{array}{c}(-) 0.013 \\
(0.015)\end{array}$ & $\begin{array}{c}0.013 \\
(0.016)\end{array}$ & $\begin{array}{c}0.009 \\
(0.015)\end{array}$ & $\begin{array}{c}(-) 0.030 \\
(0.022)\end{array}$ & $\begin{array}{l}0.039^{\star} \\
(0.023)\end{array}$ & $\begin{array}{c}0.004 \\
(0.023) \\
(-\end{array}$ & $\begin{array}{c}0.011 \\
(0.022)\end{array}$ & $\begin{array}{c}(-) 0.007 \\
(0.029) \\
(-\end{array}$ \\
\hline Project Org. & $\begin{array}{c}0.012 \\
(0.008)\end{array}$ & $\begin{array}{c}0.006 \\
(0.009)\end{array}$ & $\begin{array}{c}0.006 \\
(0.010)\end{array}$ & $\begin{array}{l}0.021^{* *} \\
(0.010)\end{array}$ & $\begin{array}{c}0.010 \\
(0.014)\end{array}$ & $\begin{array}{c}0.010 \\
(0.015)\end{array}$ & $\begin{array}{c}0.053^{\star \star *} \\
(0.014)\end{array}$ & $\begin{array}{c}0.000 \\
(0.014)\end{array}$ & $\begin{array}{c}0.054^{\star \star \star} \\
(0.019)\end{array}$ \\
\hline rotation & $\begin{array}{c}0.001 \\
(0.012)\end{array}$ & $\begin{array}{c}0.003 \\
(0.014)\end{array}$ & $\begin{array}{c}(-) 0.001 \\
(0.015)\end{array}$ & $\begin{array}{l}(-) 0.003 \\
(0.014)\end{array}$ & $\begin{array}{c}(-) 0.004 \\
(0.021)\end{array}$ & $\begin{array}{c}0.001 \\
(0.022)\end{array}$ & $\begin{array}{c}0.021 \\
(0.021)\end{array}$ & $\begin{array}{c}0.007 \\
(0.021)\end{array}$ & $\begin{array}{c}0.015 \\
(0.027)\end{array}$ \\
\hline $\begin{array}{l}\text { Quality } \\
\text { circles*TQM }\end{array}$ & $\begin{array}{c}(-) 0.005 \\
(0.064)\end{array}$ & $\begin{array}{c}(-) 0.041 \\
(0.074)\end{array}$ & $\begin{array}{c}0.036 \\
(0.079)\end{array}$ & $\begin{array}{c}(-) 0.075 \\
(0.076)\end{array}$ & $\begin{array}{c}(-) 0.172 \\
(0.111)\end{array}$ & $\begin{array}{c}0.097 \\
(0.116)\end{array}$ & $\begin{array}{c}(-) 0.064 \\
(0.114)\end{array}$ & $\begin{array}{c}0.049 \\
(0.113)\end{array}$ & $\begin{array}{l}(-) 0.113 \\
(0.148)\end{array}$ \\
\hline $\begin{array}{l}\text { Quality } \\
\text { circles }^{*} \mathrm{TQM}^{*} \\
\text { Job rotation }\end{array}$ & $\begin{array}{c}(-) 0.093 \\
(0.073) \\
\end{array}$ & $\begin{array}{c}(-) 0.169^{\star \star} \\
(0.084) \\
\end{array}$ & $\begin{array}{c}0.075 \\
(0.089) \\
\end{array}$ & $\begin{array}{c}0.025 \\
(0.086) \\
\end{array}$ & $\begin{array}{c}0.192 \\
(0.126) \\
\end{array}$ & $\begin{array}{c}(-) 0.168 \\
(0.132) \\
\end{array}$ & $\begin{array}{c}(-) 0.154 \\
(0.129) \\
\end{array}$ & $\begin{array}{r}(-) 0.224 \\
(0.129) \\
\end{array}$ & $\begin{array}{c}0.070 \\
(0.167) \\
\end{array}$ \\
\hline $\begin{array}{l}N \text { of obs. } \\
\text { Adj. } R^{2}\end{array}$ & $\begin{array}{l}5171 \\
0.774 \\
\end{array}$ & $\begin{array}{l}5171 \\
0.590 \\
\end{array}$ & $\begin{array}{l}5171 \\
0.562 \\
\end{array}$ & $\begin{array}{l}5171 \\
0.657 \\
\end{array}$ & $\begin{array}{l}5171 \\
0.427 \\
\end{array}$ & $\begin{array}{l}5171 \\
0.375 \\
\end{array}$ & $\begin{array}{l}5171 \\
0.478 \\
\end{array}$ & $\begin{array}{l}5171 \\
0.476 \\
\end{array}$ & $\begin{array}{l}5168 \\
0.332 \\
\end{array}$ \\
\hline
\end{tabular}

${ }^{\mathrm{a}}$ Firm fixed effects and time trend were included as additional control. 
Appendix A-2. The impact of individual practices on firm average wage, corrected for serial correlation

Dep. var.: $\log$ male wage ${ }^{a}$ log female wage ${ }^{a}$ gender wage gap ${ }^{a}$

\begin{tabular}{|c|c|c|c|c|c|c|}
\hline Teams & $\begin{array}{l}0.012^{* *} \\
(0.006) \\
-0.012^{*} \\
(0.006) \\
0.024^{* * *} \\
(0.006)\end{array}$ & & & & & \\
\hline Job rotation & 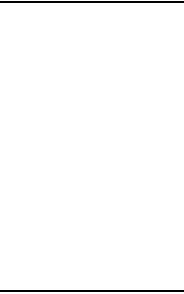 & $\begin{array}{l}0.002 \\
(0.005) \\
-0.018^{* * *} \\
(0.006) \\
0.020^{* * *} \\
(0.006) \\
\end{array}$ & & & & \\
\hline Quality circles & & 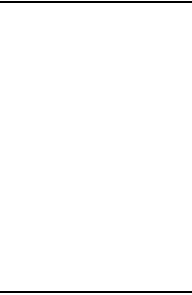 & $\begin{array}{l}-0.001 \\
(0.012) \\
0.008 \\
(0.021) \\
-0.009 \\
(0.019) \\
\end{array}$ & & & \\
\hline $\begin{array}{l}\text { Total quality } \\
\text { Management }\end{array}$ & & & 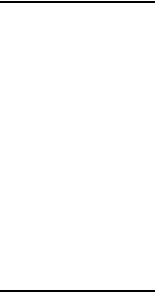 & $\begin{array}{l}-0.023 * * * \\
(0.009) \\
-0.010 \\
(0.012) \\
-0.013 \\
(0.010) \\
\end{array}$ & & \\
\hline Benchmarking & & & & 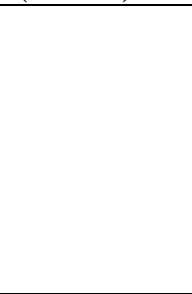 & $\begin{array}{l}0.004 \\
(0.008) \\
-0.015 \\
(0.009) \\
0.019 * * \\
(0.008)\end{array}$ & \\
\hline $\begin{array}{l}\text { Project } \\
\text { Organisation }\end{array}$ & & & & & & $\begin{array}{l}0.010 \\
(0.008) \\
-0.001 \\
(0.009) \\
0.012 \\
(0.008) \\
\end{array}$ \\
\hline
\end{tabular}

${ }^{\mathrm{a}}$ Firm fixed effects and a time trend were included as additional controls. 
Appendix A-3. The impact of individual practices on firm average wage, corrected for serial correlation

Dep. var.: log male hourly wage $\mathrm{a}^{\mathrm{a}}$ $\log$ female hourly wage ${ }^{a}$ gender hourly wage gap ${ }^{\mathrm{a}}$

\begin{tabular}{|c|c|c|c|c|c|c|}
\hline Teams & $\begin{array}{l}0.016 * * \\
(0.006) \\
-0.007 \\
(0.009) \\
0.022 * * * \\
(0.008) \\
\end{array}$ & & & & & \\
\hline Job rotation & & $\begin{array}{l}-0.013 * * \\
(0.006) \\
-0.016 \\
(0.010) \\
0.003 \\
(0.010)\end{array}$ & & & & \\
\hline Quality circles & & & $\begin{array}{l}0.031 * * \\
(0.013) \\
0.134 * * * \\
(0.039) \\
-0.103^{* * *} \\
(0.039) \\
\end{array}$ & & & \\
\hline $\begin{array}{l}\text { Total quality } \\
\text { Management }\end{array}$ & & & . & $\begin{array}{l}0.020 \\
(0.015) \\
0.024 \\
(0.018) \\
-0.004 \\
(0.019) \\
\end{array}$ & & \\
\hline Benchmarking & & & & & $\begin{array}{l}0.011 \\
(0.008) \\
-0.023 \\
(0.015) \\
0.033^{* *} \\
(0.013) \\
\end{array}$ & \\
\hline $\begin{array}{l}\text { Project } \\
\text { Organisation }\end{array}$ & & & & & & $\begin{array}{l}0.018 * \\
(0.010) \\
0.005 \\
(0.012) \\
0.013 \\
(0.012)\end{array}$ \\
\hline
\end{tabular}

${ }^{\mathrm{a}}$ Firm fixed effects and a time trend were included as additional controls. 
Appendix A-4. The impact of individual practices on firm average wage, corrected for serial correlation

Dep. var.: log male salaried wage $\mathrm{e}^{\mathrm{a}}$ $\log$ female salaried wage $\mathrm{a}^{\mathrm{a}}$ gender salaried wage gap ${ }^{a}$

\begin{tabular}{|c|c|c|c|c|c|c|}
\hline Teams & $\begin{array}{l}0.014 \\
(0.010) \\
0.002 \\
(0.009) \\
0.012 \\
(0.011)\end{array}$ & & & & & \\
\hline Job rotation & & $\begin{array}{l}0.021^{* *} \\
(0.009) \\
0.016^{*} \\
(0.009) \\
0.006 \\
(0.011)\end{array}$ & & & & \\
\hline Quality circles & & & $\begin{array}{l}-0.003 \\
(0.029) \\
-0.014 \\
(0.030) \\
0.012 \\
(0.032) \\
\end{array}$ & & & \\
\hline $\begin{array}{l}\text { Total quality } \\
\text { Management }\end{array}$ & & & & $\begin{array}{l}-0.011 \\
(0.016) \\
-0.004 \\
(0.014) \\
-0.008 \\
(0.017) \\
\end{array}$ & & \\
\hline Benchmarking & & & & & $\begin{array}{l}0.009 \\
(0.012) \\
0.014 \\
(0.012) \\
-0.005 \\
(0.016) \\
\end{array}$ & \\
\hline $\begin{array}{l}\text { Project } \\
\text { organisation }\end{array}$ & & & & & & $\begin{array}{l}-0.032 * * * \\
(0.011) \\
0.003 \\
(0.012) \\
-0.036^{* * *} \\
(0.012) \\
\end{array}$ \\
\hline
\end{tabular}

${ }^{\mathrm{a}}$ Firm fixed effects and a time trend were included as additional controls 